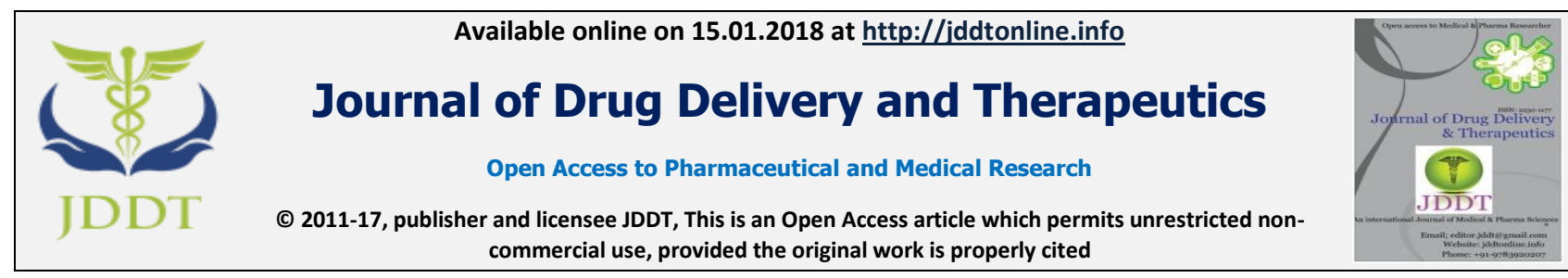

Open $\odot$ Access

Research Article

\title{
ANTICONVULSANT EFFECT OF AQUEOUS EXTRACT OF AERIAL ROOT OF FICUS RELIGIOSA IN ANIMAL MODELS
}

\author{
Smita Singh ${ }^{1 *}$, Md. Parwez Ahmad ${ }^{1}$, Deependra Prasad Sarraf ${ }^{2}$, Chandan Mishra $^{1}$, Prabin Kumar Singh ${ }^{3}$, \\ ${ }^{1}$ Department of Pharmacology, National Medical College Teaching Hospital, Birgunj, Nepal \\ ${ }^{2}$ Department of Pharmacology, BPKIHS, Dharan, Nepal \\ ${ }^{3}$ Department of Paediatrics, Narayani Sub-regional Hospital, Birgunj, Nepal
}

\section{ABSTRACT}

Ficus religiosa commonly found tree in Indian sub-continent has numerous neuro-pharmacological effects including epilepsy in traditional medicine. Therefore, anticonvulsant effect of aqueous aerial root extract of F. religiosa at oral doses 25, 50 and 100 $\mathrm{mg} / \mathrm{kg}$ was studied using Maximum electroshock (MES) and Pentylenetetrazole (PTZ) induced seizure models in mice. F. religiosa showed anticonvulsant effect dose dependently in MES \& PTZ test. In MES model F. religiosa 100mg/kg significantly $(p<0.05)$ lowered duration of Tonic hind limb extension. In PTZ model, all three doses of F. religiosa significantly $(p<0.05)$ increased latency to convulsion. These findings thus provide scientific evidence in support of the folkloric use of this plant in the management of epilepsy.

Keywords: Anticonvulsant, Ficus religiosa, Maximum electroshock, Pentylenetetrazole, Root

Article Info: Received 04 Nov, 2017; Review Completed 14 Dec, 2017; Accepted 15 Dec, 2017; Available online 15 Jan, 2018

Cite this article as:

Smita S, Ahmad MP, Sarraf DP, Mishra C, Singh PK, Anticonvulsant effect of aqueous extract of aerial root of ficus religiosa in animal models, Journal of Drug Delivery and Therapeutics. 2018; 8(1):13-16

DOI: http://dx.doi.org/10.22270/iddt.v8i1.1543

*Address for Correspondence

Smita Singh, Department of Pharmacology, National Medical College Teaching Hospital, Birgunj, Nepal, Email: ssktm3@gmail.com

\section{INTRODUCTION}

Epilepsy is a disorder of the brain characterized by tendency to have recurrent seizure, affecting at least 50 million people worldwide, among which $80 \%$ are in developing countries ${ }^{1}$. Despite of development of newer anti-epileptic drugs like Leviteracetam, Lamotrigine, Topiramate etc. Satisfactory seizure control has not yet been established. In addition anticonvulsant drugs have serious side effects which necessitates development of new drugs or lead molecules with more suitable margins of safety, efficacy, cost effectiveness and tolerability $^{2}$. Hence search for the ideal natural anticonvulsant drug still continues as Global estimates suggest that about three- fourth of human population have been relying especially on plant derived traditional medicine as they are easily assesible, cheaper and people have belief that they have lesser side effects than allopathic medicine. Therefore these days the World
Health Organization is encouraging, promoting and facilitating effective use of herbal medicine in developing countries ${ }^{3}$.

F. religiosa commonly known as peepal, belongs to family Moraceae and is widely distributed in Indian subcontinent. It has mythological, religious and medicinal importance ${ }^{4}$. F. religiosa different parts have been used in traditional medicine to treat different disorders like tooth ache, sexual disorders, arthritis, elephantiasis, stomatitis, malarial fever, respiratory disorders including epilepsy ${ }^{5}$. Many of this traditional uses have been validated by scientific researches such as the Methanolic bark extract of F. religiosa has analgesic and anti-inflammatory effect ${ }^{6}$, Anti-oxidant effect of aqueous bark extract of F. religiosa ${ }^{7}$, Anti- ulcer activity of of ethanolic extract of stem bark ${ }^{8}$, the Methanolic extracts of Fig possesses Anti-amnesic ${ }^{9}$ and Anticonvulsant property of fig of F. religiosa ${ }^{10}$. Despite 
of wide ethno-medicinal use of this plant only few experimentally validated results are available in use of adventitious roots as an anticonvulsant in Nepal. In the present study aqueous extract of F. religiosa has been prepared using soxhlet apparatus and anticonvulsant effect has been evaluated using maximal electrical shock (MES) and Pentylenetetrazole (PTZ) induced convulsion models in mice. This study might open a pathway for the development of plant derived new lead molecule for the treatment of Epilepsy.

\section{MATERIAL AND METHODS}

\section{Design of study}

Quantitative experimental study conducted in mice

\section{Drugs and chemicals}

Pentylenetetrazole (Sigma chemicals, USA), Phenytoin (M-Toin, Medopharm, India), Diazepam (Valium, Piramal Healthcare, India) were used in the experiment.

\section{Collection of plant material and preparation of extract}

The aerial root of F. religiosa was collected from garden of BPKIHS, Eastern part of Nepal, with Latitude and Longitude $26^{\circ} 49^{\prime} 0^{\prime \prime} \mathrm{N}$ and $87^{\circ} 17^{\prime} 0^{\prime \prime}$ E respectively. The specimen of test drug was deposited in National Herbarium and Plant Laboratories, Kathmandu (The voucher no is 5021). The material was washed, shade dried for seven days and then grinded to fine powder. About $10 \mathrm{gm}$ of fine powder was taken in clean sterile Soxhlet apparatus (Jain Scientific Glass Works Ambala Cantt; Extraction Pot: $250 \mathrm{ml}$; Soxhlet chamber size: $100 \mathrm{ml}$; Heater: DICA India) and extracted with $150 \mathrm{ml}$ of distilled water continuously for $6 \mathrm{hrs}$. The extract obtained was filtered with Whatman filter paper 1 . The filtrate was evaporated at $50^{\circ} \mathrm{C}$ for a brief time interval, stopped just before the apparently saturated solution precipitated and left in room temperature till the moisture dried. Finally percentage yield was $20 \%(\mathrm{w} / \mathrm{w})$ which were used depending upon the experiment.

On the day of experiment, $2.5 \mathrm{mg} / \mathrm{ml}, 5 \mathrm{mg} / \mathrm{ml}$ and $10 \mathrm{mg} / \mathrm{ml}$ solution in distilled water were prepared such that $1 \mathrm{ml} / 100 \mathrm{gm}$ mouse body weight could be given in test drug groups for desired test dose of $25 \mathrm{mg} / \mathrm{kg}$, $50 \mathrm{mg} / \mathrm{kg}$ and $100 \mathrm{mg} / \mathrm{kg}$ respectively. The test drug F. religiosa and vehicle control were given through oral route with the help of oro-gastric tube whereas standard control route varied with the experiment ${ }^{11}$.

\section{Animals}

Healthy, twelve weeks old, Swiss albino mice (25$30 \mathrm{gm}$ ) of either sex bred in the breeding house of Bisheshwar Prasad Koirala Institute of Health Sciences (BPKIHS), Dharan, Nepal were used. The study was conducted in the Laboratory of Department of Clinical Pharmacology and Therapeutics of BPKIHS. Experiments were performed between 8:00 and 16:00 h in March-May 2014 when the average temperature was between 11 to $21^{\circ} \mathrm{C}$. The animals were maintained under controlled room temperature $\left(22 \pm 3^{\circ} \mathrm{C}\right)$ light and dark (12:12hour) conditions. They were given food pellets and water ad libitum but fasted overnight before the experiment. Animals were randomly selected and six mice were used per group in all experiments. All experimental protocols were approved by the Institutional Ethical Review Board of BPKIHS. (No: 898/070/071).

\section{Phytochemical screening}

It was done qualitatively to identify the presence of various chemical constituents. Glycoside was detected by water and sodium hydroxide solution, flavonoids with $\mathrm{Mg}$ and $\mathrm{HCl}$, tannins with ferric chloride solution, steroids with chloroform and sulphuric acid whereas saponins by the capability of extract to produce suds. These were identified by characteristic color changes using standard procedures ${ }^{12}$.

\section{Acute toxicity study}

A toxicity study of the aqueous extract of F. religiosa was performed according to OECD guideline no. 425 using Swiss albino mice $(25-30 \mathrm{~g})$. Six mice were serially administered with the aqueous extract of $\mathrm{F}$. religiosa upto dose limit of $2000 \mathrm{mg} / \mathrm{kg}$ as recommended in the guideline. After administration of the dose, each animal was observed every hour for signs of toxicity and abnormality in behavior up to 48 hours. Subsequently daily observations were made for toxicity and mortality up to 14 days ${ }^{13}$.

\section{Experimental design}

The animals were divided into six in each group of control, standard control and test drug in each experiment. The experimental animals were given drugs as following.

Group 1: Distilled water/ PTZ 40mg/kg IP

Group 2: F. religiosa $25 \mathrm{mg} / \mathrm{kg}$

Group 3: F. religiosa $50 \mathrm{mg} / \mathrm{kg}$

Group 4: F. religiosa $100 \mathrm{mg} / \mathrm{kg}$

Group 5: The standard control varied with the experiment

\section{Maximal Electroshock Seizure (MES) test}

One hour after oral drug administration mice were subjected to alternating current of $150 \mathrm{~mA}$ from a convulsiometer (Techno, India) for $0.2 \mathrm{sec}$ through a pair of electrodes attached to each ear ${ }^{14}$. Each animal was observed for 2 complete minutes. Parameters observed and documented a. Duration of tonic hind limb extension (THLE).

b. Percentage of animals protected against seizure (PAS) in one hour.

Phenytoin $(20 \mathrm{mg} / \mathrm{kg}$ per oral) was the standard control for this test ${ }^{15}$.

\section{Pentylenetetrazole (PTZ) induced seizure}

After forty five mins of post dosing with the test drug (F. religiosa) mice were given PTZ $40 \mathrm{mg} / \mathrm{kgIP}{ }^{14}$. Diazepam (4 mg/kg; IP) served as standard control ${ }^{16}$ which was administered fifteen mins prior to experiment. Parameters observed and documented 
a) Latency to seizure onset.

b) Percentage of animals protected against seizure (PAS) in one hour.

Seizure was defined as jerky movements of whole body or convulsion ${ }^{17}$. Each mouse was observed for one whole hour for the occurrence of seizure.

\section{Statistical analysis}

All data were presented as Mean \pm Standard Error of Mean (SEM). Statistical differences between the test drug and standard control groups were calculated using Mann - Whitney U test. Results were considered to be significant at $\mathrm{p}<0.05$.

\section{RESULTS AND DISCUSSION}

In the acute toxicity study, neither death nor any observable neurobehavioral effects were observed. Due to lack of observable toxicity, LD50 wasn't determined. In the preliminary dose determining study, we arbitrarily selected dose of $200 \mathrm{mg} / \mathrm{kg}$ p.o. of F. religiosa and evaluated its activity in the PTZ $(40 \mathrm{mg} / \mathrm{kg}$, i.p.) induced convulsions in mice. However, at this dose of the extract, PTZ-induced convulsions were completely inhibited. Owing to the high potency, a subsequent study was conducted at reduced doses of 100, 50 and 25 $\mathrm{mg} / \mathrm{kg}$.
The anticonvulsant effect of aerial root of F. religiosa was determined using Maximal Electroshock seizure and Pentylenetetrazole induced seizure models.

MES is a valid model of screening potential anticonvulsant drugs as well as to identify compounds which prevent seizure spread ${ }^{18}$. The drugs which inhibit MES induced seizures mostly inhibit the sodium current and block the repetitive firing of neurons ${ }^{19}$.

PTZ induces clonic seizures ${ }^{18}$ by acting as an antagonist at the $\gamma$-aminobutyric acid type $\mathrm{A}\left(\mathrm{GABA}_{\mathrm{A}}\right)$ receptor. So, convulsions produced by PTZ can be effectively blocked by Diazepam which increases frequency of opening of $\mathrm{GABA}_{\mathrm{A}}$ receptor ${ }^{20}$.

In our study aqueous aerial root extract of F. religiosa dose dependently decreased the duration of tonic hind limb extension and latency to onset of convulsion in MES and PTZ induced seizure models respectively. In MES test, F. religiosa $100 \mathrm{mg} / \mathrm{kg}$ showed $100 \%$ protection against seizure in $1 \mathrm{hr}$ similar to that of Phenytoin. Similar to Diazepam, FR $100 \mathrm{mg} / \mathrm{kg}$ completely inhibited the onset of PTZ induced seizure. In both the test models, the extract demonstrated a significant increase in latency of onset of convulsion ( $\mathrm{p}$ $<0.05)$ compared with the vehicle control in unprotected animals. (Table $1 \& 2$ )

\section{Table 1: Comparison of mean duration of tonic hind limb extension in MES test}

\begin{tabular}{|c|c|c|}
\hline Experimental Groups & Mean duration of THLE \pm SEM & $\operatorname{PAS}(\%)$ in $1 \mathrm{hr}$ \\
\hline Vehicle control & $13.50 \pm 0.42$ & 0 \\
\hline Phenytoin & $(15)$ & 100 \\
\hline F. religiosa $25 \mathrm{mg} / \mathrm{kg}$ & $4.50 \pm 2.84^{\mathrm{a}}$ & 66.67 \\
\hline F. religiosa $50 \mathrm{mg} / \mathrm{kg}$ & $2.33 \pm 2.33^{\mathrm{a}}$ & 83.34 \\
\hline F. religiosa $100 \mathrm{mg} / \mathrm{kg}$ & - & 100 \\
\hline
\end{tabular}

Table 2: Comparison of mean latency of convulsion in PTZ induced seizure

$\begin{array}{lcc}\text { Experimental Groups } & \text { Mean latency of convulsion } \pm \text { SEM } & \text { PAS( \% ) in } \mathbf{~ h r} \\ \text { Vehicle control } & 65.33 \pm 0.71 & 0 \\ \text { Phenytoin } & - & 100 \\ \text { FR } 25 \mathrm{mg} / \mathrm{kg} & 134.66 \pm 19.42^{\mathrm{a}} & 0 \\ \text { FR } 50 \mathrm{mg} / \mathrm{kg} & 152.50 \pm 24.37^{\mathrm{a}} & 0 \\ \text { FR } 100 \mathrm{mg} / \mathrm{kg} & - & 100 \\ \mathrm{n}=6, \text { Values are expressed as Mean } \pm \text { SEM, Mann }- \text { Whitney U test, }{ }^{\mathrm{a}} \mathrm{P}<0.05 \mathrm{v} / \mathrm{s} \text { vehicle control }\end{array}$

The preliminary phyto-chemical analysis revealed the presence of flavonoids, glycosides, tannin and saponin. Different literatures have shown that saponin has its anticonvulsant effect due to blockade of voltage dependent $\mathrm{Na}+$ channels $^{15}$, Modulation of GABAergic functions ${ }^{16}$, blockade of NMDA receptor ${ }^{17}$. Thus our study scientifically proves the use of root of F. religiosa in epilepsy which might be due to presence of saponin. 


\section{CONCLUSION}

Results of the present study clearly indicate that oral administration of aqueous aerial root extract of $\mathrm{F}$. religiosa at different doses of 25,50 and $100 \mathrm{mg} / \mathrm{kg}$ in MES and PTZ induced seizure model produces a significant dose dependent anticonvulsant activity. Observations of the present study could justify, the

\section{REFERENCES}

1. Anovadiya AP, Jayesh JS, Vadgama VK \& Tripathi CB, Evaluation of antiepileptic and memory retention activity of curcumin per se and incombination with antiepileptic drugs, Asian J Pharm Clin Res, 2013; 6(2): 145.

2. Keshavarz M, Showraki A \& Emamghoreishi M, Anticonvulsant Effect of Guaifenesin against Pentylenetetrazol-Induced Seizure in Mice, Iran J Med Sci, 2013; 38(2):116.

3. Dhar U, Manjkhola S, Joshi M, Bhatta A et al, Current status and future strategy for development of medicinal plant sector in Uttranchal, India, Curr Sci, 2002; 83(8):956-964.

4. Panchawat S. Ficus religiosa Roxb. (Peepal): A PhytoPharmacological Review, IJPS, 2012; 1(1):435-446.

5. Kaur A, Rana AC, Tiwari V, Sharma R and Kumar K, Review on Ethnomedicinal and Pharmacological Properties of Ficus religiosa, JAPS, 2011; 01(08):06-11.

6. Sreelekshmi R, Latha PG, Arafat MM, Shyamal S et al, Antiinflammatory, Analgesic and Anti-lipid peroxidation studies on stem bark of Ficus religiosa Linn, Nat Prod Radian, 2007; 6(5):377-381.

7. Kirana H, Agrawal SS \& Srinivasan BP, Aqueous extract of Ficus religiosa Linn. Reduced oxidative stress in experimentally induced type 2 diabetic rats, Ind J Exp Biol, 2009; 47:822-826.

8. Khan SA, Hussain SA, Jais AM, Zakaria Z \& Khan M, Antiulcer activity of Ficus religiosa stem bark ethanolic extract in rats, J Med Plants Res, 2011; 5(3);354-359.

9. Kaur D, Singh B and Goel RK, Antiamnesic effect of Ficus religiosa in scopolamine induced anterograde and retrograde amnesia, Pharm Biol, 2010; 48(2):234-240.

10. Singh D and Goel RK, Anticonvulsant effect of Ficus religiosa: Role of Serotonergic pathways, J Ethnopharmacol, 2009; 123(2):330-334. folkloric use of this plant in the management of epilepsy. However further studies are required to establish its exact mode of action, isolation and characterization of constituents responsible for activity.

\section{DECLARATION OF INTEREST:}

The author reports no conflict of interests.

11. Panday DR \& Rauniar GP, Effect of root- extracts of Ficus benghalensis (Banyan) in memory, anxiety, muscle coordiantion and seizure in animal models, BMC Complementary and Alternative medicine, 2016; 16:429.

12. Ghani A, Medicinal Plants of Bangladesh: Chemical Constituents and Uses, Asiatic Society of Bangladesh, Dhaka, Bangladesh, 2nd edition, 1998.

13. Patil MS, Patil CR, Patil SW \& Jadhav RB, Anticonvulsant activity of aqueous root extract of Ficus religiosa, J Ethanopharmacol, 2011; 133(1):92.

14. Singh K, Rauniar G \& Sangraula H, Experimental study of neuropharmacological profile of Euphorbia pulcherrima in mice and rats, J Neurosci Rural Pract, 2012; 3:311.

15. Vogel H, Vogel HW, Schölkens BA, Sandow J, Müller G, Vogel WF. Drug Discovery and Evaluation: Pharmacological Assays. 2nd ed. Springer; 2002. P.146-151.

16. Medhi B, Prakash AJ. Practical Manual of Experimental and Clinical Pharmacology. 1st ed. Jaypee Brothers, Medical Publishers; 2010. P. 45-48.

17. Kulkarni SK. Handbook of Experimental Pharmacology. $3^{\text {rd }}$ ed. Vallabh Prakashan: Panjab University Chandigarh; 2010. P 36-39.

18. Singh D, Singh B and Goel RK, Role of saponins for the anticonvulsant effect of adventitious roots of Ficus religiosa, Pharm Biol, 2012; 50 (7):816.

19. Wigdor S, Wilcox GL, Central and systemic morphineinduced antinociception in mice: contribution of descending serotonergic and noradrenergic pathways, J pharmacol Exp Ther, 1987; 242:90-95.

20. Macdonald RL, Kelly KM, Antiepileptic drug mechanism of action, Epilepsia, 1995; 36:2-12. 